\title{
Exploring Language Style in Makassar Cultural Tourism
}

\author{
Ratnawati \\ ratnawati.ratnawati@umi.ac.id \\ Akademi Bahasa Asing UMI \\ Rosmiaty \\ rosmiatypammu@gmail.com \\ Politeknik Sandi Karsa \\ Nurfaizah \\ Nurfaizah121@gmail.com \\ Akademi Bahasa Asing UMI
}

\begin{abstract}
The purpose of this study is to analyze the language style of Makassar cultural tourism in communicating with English native speakers which tried to find out the kinds of language style that are mostly used in the cultural tourism within Makassar. This study focused on Matin Joos' theory which discussed about language style. Then, it was analyzed by using descriptive approach. The study used six cultural tourism videos on YouTube as the instrument to find out more valid data. The result of the study shows that Formal style was mostly used by tourist in conversation in which the authors found five times, followed by casual style found in fourth, casual style only one times, and intimate style for a twice. The findings of the study would serve as a reference to teaching English for tourism in Indonesian context to accommodate better communication in English.
\end{abstract}

Keywords: language style, cultural tourism, makassar, communication.

\section{INTRODUCTION}

Humans are social beings that need to communicate with other human in their lives. Language is considered as important aspect as a tool of communication in social life. Language is a mean of transferring the information or idea that has meanings which is understandable. communication refers to the transmission of information (a message) between a source and a receiver using a signaling system; restricting this notion to "human communication". In communication, people have many ways to communicate with other people. People use language as a tool of communication to say their wants, messages, information, and ideas to other people (Cryatal 2013). 
When people interact with others, it must occur of communication. Their communication will be influenced by their circumstance or the social context in which they have many different styles of language depending on situation and condition of it is social context. According to Chaika (1982), In expressing or delivering ideas in both forms, spoken, and written language, people have and use their own style because it is related to the social aspect. Chaika in Octaviana (2016) describes six characteristics of style, those are :

1. Style forms a communication system in its own right.

2. Style tells how interpret a massage.

3. Style forms a mini communication system that works along with the language itself.

4. Style controls their interaction.

5. Style is so integral with a social function that interaction cannot go ahead if one does not speak with the right style.

Moreover, when people talk about language, of course it cannot be separated with sociolinguistic, because language has the important role to interact in society. Language and social interaction is the basic elements in sociolinguistic. Language is a means of communication. Sociolinguistic is the study of language in its social context and the study of social life trough linguistic (Wardough in Sabillah, 2002).

In sociolinguistics, there are a variation of language. It is a part of sociolinguistic itself. There are many different types of language variation. Language style is one of types of language variation. According to Labov (1972), style involves the way in which the same speaker, use language in which the same speakers talk differently on different occasions rather than the ways in which different speakers talk differently from each other. Style also controls social interactions. Most interestingly, style gives its own messages, messages that are not supposed to be given via the linguistics system proper. The reason for this can be understood only in the context of sociology of language (Chaika, 1982).

The usage of different language style can also be found and observed in social media. Social media is the collective of online communications channels dedicated to community-based input, interaction, content-sharing and collaboration. In this research focus on language style found in YouTube channel specially on content about Makassar Local Tourism. Nowadays, people can get the latest update information from anywhere, it is because the development of technology. In this case, YouTube as the most popular social media in the world. So, it will be easier to finding language style on YouTube.

Makassar is one of big city in South Sulawesi with many tourist attractions. Many foreign tourists and local tourists choose Makassar as destination based on data by Sindonews tourist arrivals in Makassar in the past three years have increased. The number of domestic tourists during the last there years reached 15.337 .897 people, and for foreign tourist 284.778. people. It is showed that there is some interesting things in Makassar, people who come from other country have their own style and uniqueness, one of them is language. Everyone has a different way in describing something. This is the reason of the authors taking tittle "Language style in Makassar local tourist. Based on the background above, the problems of this study are follows; (1)what are types of language style used in Makassar local tourism? And (2) How are the language style used in Makassar local tourism? 


\section{Language Style}

Chaika (1982: 29) states that language style is the way people use the language in communication, it can be written or oral language. Language style refers to the selection of linguistics form to convey social or artistic effects. Style also acts as a set of instruction. We manipulate other with style; even we are manipulated ourselves whether consciously or unconsciously. In doing communication people usually use formal or informal language which depend on the situation they are communicating with others. Style also tells the listener to take what is being said, seriously, ironically, humorously or in some other ways. Chaika (1982: 29) states that language style is the way people use the language in communication, it can be written or oral language. Language style refers to the selection of linguistics form to convey social or artistic effects. Style also acts as a set of instruction. We manipulate other with style; even we are manipulated ourselves whether consciously or unconsciously. In doing communication people usually use formal or informal language which depend on the situation they are communicating with others. Style also tells the listener to take what is being said, seriously, ironically, humorously or in some other ways.

From the statement above, we understand that style is the way how people convey ideas or messages. It is easier to receive ideas or messages if we have known the condition and style used by the speaker or author. It means that how the way of speaker or author delivers his or her ideas or messages in formal or informal occasion: seriously, ironically, or humorously style. Dyer (2004:74), argues that styles not only do some of the same linguistic features in pattern of both regional and social dialect differentiation, but they also display correlations with other social factors. From Dyer statement above, style displays the correlation between social factors and the language that is used by the society. It means that the society can predict what the style that they will use in their communication according to the running situation.

In addition, Sincalair, (2007) in Thomas and Wareing (2005: 146), state that people may use different style in the way they talk depends on the situation and context they are talking in. This account is based on the premises that people are mainly seeking to show solidarity and approval there, dealing with others. According to the statement above, the use of language style occurs during conversation where it depends on situation and context they talk about. It is used in order to make the listener and reader understand. The style of language in a communication mainly focuses on an intended social message rather than gets the message of communication. Chaika (2008: 31) states that communication occurs transformation messages from the speaker to the listener, so they are conveyed by intonation or infection that are given by style. Actual words are used only on the rare occasions that the offending party is too abuse to get "the message". It must be emphasized that the social message conveyed by style is not coded directly into actual words that mean what intended social message is. In conclusion, language style is the way people manipulate others and control their interaction in bringing messages or ideas conveyed in word and tone of voice. The characteristics of language style are: selecting and choosing the linguistic forms appeared from a person or group of people.

\section{Local Tourism}

Tourism is a complex exertion because many activities that related in implementation of tourism. Many tourism activities, such as hotel management, travel, and the others. Tourism is a journey from one place to other place, done by individual or group, as effort to seek balance or accord or happiness with our life. Environment and social dimension, culture, 
nature, and science (Khodhyat 1983). Indonesia is big city with many tourist attractions. Every year many people choose Indonesia as a tourist destination. Besides to improving economic aspec from tourism also it is a good way to introduce Indonesia tourist attraction to the word. Many local tourisms enjoy travelling in Indonesia. Tourist arrivals in Indonesia have increased every year. Also in Makassar, many foreign tourist and local tourist choose Makassar as tourist destination. Formerly also known as Ujung Pandang, Makassar is a thriving port city and the provincial capital of South Sulawesi. The number of domestic tourists during the last there years reached 15.337.897 people, and for foreign tourist 284.778. Makassar is the one of most colorfully cosmopolitan cities in the country. The city most famous part is the Pantai Losari ot the Losari Beach, where tourist may catch picturesque scenes from the sea and visit the various food stalls, and the famous floating mosque Masjid Amirul mukminin.

Based on holidify.com The top activities to do for tourist when they come in Makassar were Fort Rotterdam, Losai Beach, Paotere Harbour, Pasir Putih Island, etc. The best time to Visit Makassar is From July to September since December-February are the busiest with torrential rain. The springs months of March-May are warm with highest temperatures ranging between $91.2^{\circ} \mathrm{F}\left(32.9^{\circ} \mathrm{C}\right)$ and $87.8^{\circ} \mathrm{F}\left(31^{\circ} \mathrm{C}\right)$.

\section{Language Style in social media}

Social media is the term often use to refer to new forms of media that involve interactive participation. Although the term social media has taken on numerous meanings and is somewhat open to interpretation as the domain is constantly reinventing itself, generally, the term refers to "websites and applications used for social networking" (Oxford Dictionaries, 2012) in Azizah (2019). There are many social media sites or applications that familiar in our society, for example, Instagram, Facebook, WhatsApp, YouTube, Twitter, Snapchat, etc. The easy of getting the application and make the account are the reasons why people use and interest in social media. Previously, social media in society is estimated as an entertaining thing. But now, many people use social media because estimate the business aspect. People get some money from their social media account and make that as an occupation. For example, In YouTube, people making a video and publish that on YouTube. We usually called that occupation as a Youtuber or Vlogger. We also called that occupation as a passionpreneur because they make video content that agrees with their own passion, for example, Beauty Vlogger, Food Vlogger, Travel Vlogger, etc

The users of social media come from all over the world, each bringing their backgrounds and cultures into the mix (Boyd \& Ellison, 2007; Kelly-Holmes \& Pietikäinen, 2012) in Azizah (2019). Therefore, social media has various characteristics of language style. It depends on who is the user, who is the writer or author of the topic, who is the target, and what is being shared. In other words, social media is something that pays attention to the languages used in different manners and for different purposes.

Social media use the formal language style when the topic that shared is a formal topic such as news. The author of news is commonly a reporter that has to use the formal language oftentimes. The target or the readers of the topic are the citizens, so the language that users should be in a formal style to the reader got the point of the news. This is important because social media allows people to share a topic or any other in a different language. 


\section{METHOD}

In conducting this study, the authors used a descriptive research approach. The authors used this method because the research basically aims to describe the data in the form of word or spoken text. In addition, the data are describes descriptively based on research problems. The research intends to describe What and how are the language style used in Makassar local tourism. In this research, the data sources were from sentences or utterances spoken by tourists in youtube videos that focus on the content about Makassar Local Tourism. In collecting data, the the authors followed the steps below:

1. First, the authors categorized the data in accordance with the kinds of language based on Matin Joos theory .

2. Second, the authors interpreted and describe how are the language style used in Makassar local tourism.

\section{FINDINGS AND DISCUSSIONS}

Teaching activities were done by utilizing movies combined with discovery learning. According to Schunk (2008), discovery learning is defined as a method of constructing and testing hypothesis. It means that the students obtain knowledge by themselves. Kirschner, Sweller, \& Clark (2006) argue that this method can be related to problem-based, inquiry, experiential, or constructivist learning. Students find information and knowledge through observations. It includes inductive reasoning because it moves from a specific topic to formulating rules and principles.

In these finding, the authors present the findings took from Sentence utterances spoken by tourists on YouTube videos. In this section, the the authors provide the findings with interpretation in each paragraph aims to make the reader easy reading this research. The findings are based on both statements of the problems what types of language style used in Makassar local tourism and How are the language style used in Makassar local tourism. From six video, the authors found four types of five types of language style based on Martin Joss theory, that are formal style, consultative style, casual style, and intimate style. On the Formal style the authors found five data. On the consultative style the authors found four data, on the casual style the authors found one data and the last is intimate style the authors found two data.

\section{Formal Style \\ Data 1 \\ Locals : It is my family \\ Tourist : Halo, Family.}

From the dialogue, the tourist just walking around in Losari Beach, and then there are a local came and talk to the tourist and showing the family who come with him.

\section{Analysis}

From the data above, It is little awkward when you meet someone for the first time and spontaneously showing their family to you that is why when the Locals say " It is my family" the tourist answer by saying "Hi, Family". It is one of polite sentence that the tourist can say in this situation. 


\section{Data 2}

Tourist : Good Afternoon, I am Robert

Student : Good Afternoon, I am Ryan

From the dialogue, the tourist walking from Losari Beach to Fort Rotterdam and meet with a group of students and the tourist opened their conversation by introducing oneself to the student. By polite gesture and friendly.

\section{Analysis}

According to Joos (1976) this conversation is considered as formal style. The choice of words which used by tourist is formal, here also using the correct grammar. Besides on the sentence "Good Afternoon, I am Robert" this is polite sentence used by tourist in a formal situation. Say good afternoon is one of form expression familiarity indicated by tourist which made the atmosphere of the meeting more meaningful.

\section{Data 3}

Tourist : Nice to meet you Ryan.

Student : Nice to meet you too, Sorry where have you been?

Tourist : I have been nowhere yet, I have been only here.

From the dialogue, After the conversation about few second the tourist want to continued his journey and ended their conversation.

\section{Analysis}

From the data above, this conversation happens when the tourist going to continue his journey. It is one of characteristic of formal style. Formal style generally used in formal situation such as when we meet a new people. The tourist saying "Nice to meet you" to end their conversation with the student. It means that the vocabulary which is used in formal style is also extensive and used standard speech.

\section{Data 4}

Tourist : Hi, everyone.

The tourist arrived in the Sultan Hasanuddin International Airport and explain that she will be taking you to Makassar the $16^{\text {th }}$ largest Indonesia city at the largest on Sulawesi Island.

\section{Analysis}

From the data above, includes the Formal style because the sentence that is produced is standard sentence and relatively normal. In the sentence of Hi everyone is common sentence we usually use but also polite to start greeting to other. 


\section{Data 5}

Tourist : Welcome to Makassar

Altough the tourist doing the conversation not directly face to face with someone they also start opening in the video with polite sentence.

\section{Analysis}

Generally, in opening greeting the video everyone has a unique way to express. Many vloggers use sentences that are more friendly to feel more closer with their viewer. But, in this video the tourist starts opening the video by saying "Welcome to Makassar" sounds petty but still polite that is why this sentence included in category formal style.

\section{Consultative Style \\ Data 6 \\ Tourist : Take a photo? \\ Locals : Yes take a photo}

The locals that come to talk to the tourist to take a picture with their family and then the tourist take a picture with the locals family by holding each other.

\section{Analysis}

From the sentence shown that it is included into consultative style. According to Martin Joss (1976), consultative style is a style that shows our norm for coming to terms with strangers who speak our language but whose personal stock of information might be different. Consultative style is though formal enough but lower than formal style. Based on the conversation above take a photo? yes take photo, it is short sentence and less serious between locals and the tourist.

\section{Data 7}

Student : May I take your time about three minutes?

Tourist : Wow, uhhuhh okay go ahead.

The dialogue happens when the tourist walking from Losari Beach to Fort Rotterdam and meet a group of students. At the first the tourist indeed wants to say greeting to the student but accidently the student have exercise from their school to interview some tourist around Fort Rotterdam.

\section{Analysis}

From the data above, the sentences that utterance by tourist included to consultative style. Consultative style is style are thought formal enough but lower than formal style. The sentence in this style usually is shorter than formal style and it is also required for everyday 
communication. When the Tourist say "Wow, uhhuhh okay go ahead" as we know that a few positive markers of consultative style can be listed such us "uhhuhh".

\section{Data 8}

Student : Do you come here with travel agent?

Tourist : Oh, no.

In the middle of the conversation between tourist and the student, the student ask the tourist if he come with travel agent or not because usually many tourist who come in Makassar use travel agent to make their travel more esier.

\section{Analysis}

Based on data above, the conversation includes into consultative style. Penlosa (1981) states consultative style is the most neutral unmarked of the style. he give emphasis by saying "Oh no" consultative style mostly has negative markers which are characterized by the other style individually.

\section{Data 9}

Tour guide: It is Balasting Kantor or Kantor Pajak

Tourist : Mmm, okay.

From the dialogue, the tourist go in to the Fort Rotterdam and accompanied by the tour guide to looking around and explain about the history of many buildings in Fort Rotterdam.

\section{Analysis}

Based on data above, the tour guide and the tourist walking and looking around Fort Rotterdam and the tour guide shown the Kantor Pajak To the Tourist which is the tour guide say "It is Balasting Kantor or Kantor Pajak" and the tourist answer by saying "Mmm, okay". The sentence that utterance by tourist is consultative style because he emphasis a few positive markers of consultative style.

\section{Casual Style}

\section{Data 10}

Tourist : Wow, you cool guys man

Based on data above, that conversation happened when the tourist just walking around in Losari Beach anda meet some kids wearing kindergarten uniform who follow the tourist everywhere he go maybe because the kids curious meet new people who look interest. The kids come to Losari Beach with their family. Their family come after picking up their child after school. 


\section{Analysis}

Based on Martin Joos theory (1976), the data above includes into casual style. Where casual style that used in daily conversation and relax situation. In the sentence of " Oh wow, yoo look cool guys man" sounds so friendly in first meeting. The tourist very enjoy to say this sentence because he say the sentence to child who wearing kindergarten uniform without feeling awkward.

\section{Intimate Style}

\section{Data 11}

Tourist : Well Marinka, I hear the locals here have six meals a day when in rome?

From the dialogue, the foreign tourist also a chef who come in Makassar with a one of Most famous Indonesia Chef , Chef Marinka as the tour guide today Walking around in Fort Rotterdam for few minute, they visit some buildings in Fort Rotterdam and chef Marinka tell the Foreign chef about the history of Fort Rotterdam.

\section{Analysis}

The reason why the sentence "Well Marinka, I hear the locals here have six meals a day when in rome?" classified into intimate style because used non-standard forms for example among family and friends. The foreign tourist sounds very have a close relation with Chef Marinka that is why he call Chef Marinka by her named.

\section{Data 12 \\ Tourist : Marinka, a gift.}

The dialogue happens in the souvenir store in Makassar, The foreign chef and and Chef Marinka want to buy some souvenir for give a gift each other.

\section{Analysis}

The data about happens on Souvenir store. classified into intimate style because used non-standard forms for example among family and friends. The foreign tourist sounds very have a close relation with Chef Marinka that is why he call Chef Marinka by her named.

\section{Discussion}

This part presents the discussion about the findings of the data analysis above based on the language style theory. According to Martin Joss (1976) defines language style as the forms of the language style which speaker used and depends on the degree of formality and Joos divides the style of language into five styles. Those are frozen, formal style, consultative style, casual style, and intimate style. On the findings above, the authors found some types of language style that used in Makassar local tourism, those are: on the formal style, the authors found Five data that include into formal style. On the consultative style, the authors found four data that include into consultative style. On the casual style, the authors found only one data that include into casual 
style. The last is Intimate style. In this tyle the the authors found two data that include into intimate style.

From five style that states by Martin Joos in the language style theory, the the authors did not find frozen style. According to Joos (1976), frozen style is the highest rank among the other style. This style is typically used in long sentences with good grammatical and vocabulary and it is commonly used in formal place, special event, and formal ceremony. Many tourists doing vocation only for spending their time to taking walk and enjoy their spare time. Based on the findings about, in their vocation the conversation that their used mostly use formal style. The reason why the formal style mostly used in tourist conversation when their doing vocation because the tourist meet new people for first time and the best choice is used formal style when they start the conversation with locals because it will be giving more polite impression. Formal style usually used in formal situation and perfect form it means that special condition that call for dignity and seriousness. Based on the findings above, the the authors have different opinion. Martin Joos emphasized formal style only used in the formal situation and this style lower than frozen style and commonly used in formal situation. However, the the authors found that formal style not only used in the formal situation such us classroom, office, or formal events, but this style could be used in the non-formal situation by formal conversation.

Secondly consultative style, the authors found four data include into consultative style. Based on finding above, in vocation activity the language style mostly used after formal style in conversation is consultative style. Consultative style is a style that shows our norm for coming to terms with strangers who speak our language but whose personal stock of information might be different. Here means that when using style, the speaker supplies their background information and also it means that consultative style is though formal enough but lower than formal style. The sentence in this style usually is shorter than formal style and required for everyday conversation. Consultative style mostly has negative markers. It is marked say to say by the absence of all those markers which are characterized by the other styles individually. A few positive markers of consultative style can be listed such as yes, no, uhhuh, Mmm, that's right, I think so.

Third is casual style, the authors found only one data include casual style. Casual style is the style that is used in daily conversation and relax situation usually applied in friends, family, and acquaintance. Casual style refers to informal expression, ignore structure on sentence that appropriate with the grammatical rules and only focuses on meaning of an utterance. Based on finding above, casual style is style ignore the grammatical rules in the conversation, casual style focuse on the meaning of the sentence because, people who came from a country that did not use English native was easily in convey their meaning. The the authors believed that the reason why only one data found in casual style because tourist more comfortable used more polite style when meet stranger in their vocation such us formal style and consultative style.

And the last is Intimate style, the authors found two data include into intimate style. According to Martin Joos (1976), intimate style is completely private language developed within families, very close friends, lovers, and soon. The language is commonly used in incomplete sentence and does not emphasize on the articulation. This happens because there is an understanding among the speaker and listener here. It means that we can find the special term used in communication. 


\section{CONCLUSION}

In this study, the authors found four types out of five types of language style based on Martin Joss theory, they are formal style, consultative style, casual style, and intimate style. On the Formal style the authors found five data. On the consultative style the authors found four data, on the casual style the authors found one data and the last is intimate style the authors found two data. Mostly tourist used formal style on their conversation because they often meet e new people on their vocation, and formal style is the best chooses when people met a stranger and people want to talk to them. Moreover, Martin Joos emphasized Formal style used in the formal situation and this style was lower than frozen style and commonly used in formal situation such us classroom, office, or formal events, but the authors found that formal style not only characterized by formal situation, but also can be identified by formal language or formal conversation. The authors suggested to the next the authors with the same topic to find out much data I order to the next the authors could identify the data with all types of language style. Moreover, it could enrich readers knowledge and get better understanding in language style. Then, the authors suggested to the next the authors in the same topic to use many theories about language style, therefore not only focused on one theory but also relate to other theories to fill in the research gap of the study.

\section{REFERENCES}

Alston, M., \& Bowles, W. (2003). Research for social workers: An introduction to methods. Crows Nest, N.S.W: Allen \& Unwin.

Adam Damhanuri 2017. Speech Style Used in the Workplace in 500 Days of Summer Movie. Published Thesis. English Departement. English Department, Faculty of Languages and Arts, The State University of Surabaya.

Ahsanul, Language style Used By The Tour Guide and Tourists in Bali. Published Thesis, Islamic State University of Maulana Malik Ibrahim Malang 2016.

Haqqo, Octaviana Arini 2016. Language style in The Jakarta Post advertisements. Published Thesis. Malang : Islamic State University of Maulana Malik Ibrahim Malang.

Indra, Hamzah 2018. An Analysis Of Language Style Of Teneegers Found In Facebook Status. English Departement. E-Journal 2302-3546.

Sapriyani, D., at al. 2013. Analysis of Language Style Found in Novel The Lat Tycon Written by F. Scoot Fitzgerald. English Language and Literature. E-Journal 2302-3546.

Zahra. (2003). Language Style Used by Bloggers in the Blogosphere. 